\title{
Effects of exposure to three environmental chemicals on the selected biochemical parameters of the blood plasma of rainbow trout, Oncorhynchus mykiss (Walbaum)
}

\author{
Jiř́ Ǩ Rehulka, Bohumil Minařík \& Miroslav Machala
}

\begin{abstract}
Effects of exposure to three environmental chemicals on the selected biochemical parameters of the blood plasma of rainbow trout, Oncorhynchus mykiss (Walbaum). - Acta Mus. Siles. Sci. Natur. 65: 15-32, 2016.
\end{abstract}

\begin{abstract}
Rainbow trout Oncorhynchus mykiss at a weight of $115 \pm 24 \mathrm{~g}$ (mean \pm SD) were experimentally injected with di(2-ethylhexyl)phthalate (DEHP), 2,3,7,8-tetrachlorodibenzo-p-dioxine (TCDD) and gamma isomer of hexachlorocyclohexane $(\gamma-\mathrm{HCH})$ to evaluate nitrogen metabolism (total protein [TP], blood urea nitrogen, uric acid [UA], creatinine), carbohydrate metabolism (glucose), mineral metabolism (inorganic phosphate[P], total calcium $\left[\mathrm{Ca}_{t}\right]$ ), and catalytic activity of enzymes (alanine aminotransferase [ALT], aspartate aminotransferase [AST], alkaline phosphatase [ALP], lactate dehydrogenase [LD]). After 21 days, the tested xenobiotics, administered by the intraperitoneally route, caused the following effect: in comparison with negative controls, fish injected with DEHP at concentrations of 200 or $50 \mathrm{mg} \mathrm{kg}^{-1}$ of body weight were found to have a higher level of $\mathrm{P}$ and lower level of $\mathrm{Ca}_{t}$ and decreased catalytic concentrations of ALT, AST, ALP and LD in the plasma of the peripheral blood. A higher level of TP and P and a decreased catalytic concentration of ALT were found when TCDD was administered at a dose of $2 \mu \mathrm{g} \mathrm{kg}$. A decrease in the catalytic concentrations of ALT and ALP occurred in fish injected with $\gamma-\mathrm{HCH}$ in a dose of $50 \mathrm{mg} \mathrm{kg}^{-1}$. UA and $\mathrm{P}$ levels were decreased in fish injected with $\gamma-\mathrm{HCH}$ in a dose of $5 \mathrm{mg} \mathrm{kg}^{-1}$. DEHP and TCDD caused neutrophilic leucocytosis with a marked left shift. Both concentrations of $\gamma-\mathrm{HCH}$ led to an increase in polychromatophilic erythrocytes. The frequency of micronuclei varied in all experimental groups, including the controls, ranging between 0.8 and $2.1 \%$. Histological examination in fish injected with DEHP at a concentration of $200 \mathrm{mg} \mathrm{kg}^{-1}$ revealed eosinophilic droplets in the epithelium of renal tubules and histological examination in fish injected with $\gamma-\mathrm{HCH}$ at a higher concentration revealed an increased activation of sinusoidal cells in the liver, a fibrous thickening of bile duct walls, bile duct hyperplasia and a periductal inflammatory.
\end{abstract}

Key words: 2,3,7,8-tetrachlordibenzo- $p$-dioxine (TCDD), di(2-ethylhexyl)phthalate(DEHP), hexachlorocyclohexane $(\gamma-\mathrm{HCH})$, Blood plasma, Biochemical parameters, Haematology, Histopathology, Genotoxicity

\section{Introduction}

Ecotoxicologicl monitoring is conducted to gather information about the level of contamination of aquatic environment by pollutants and its purpose is also to assess the risks of the impact of contaminants on the health of fish populations. Fish and other aquatic species are exposed to a wide range of pollutants in water, food and sediments, which can affect the biotransformation reactions by inhibiting biotransformation enzymes or induce the levels of the P450 cytochromes (Machala 1993; Machala et al. 1997; Petrrivalský et al. 1997), with the biotransformation capacity varying among different fish species (Lech \& Bend 1980; Buhler \& Williams 1988) and in dependence on their degree of development (Binder \& Stegeman 1984). The essential biomarkers of the impact of environmental stress include histological methods describing liver lesions (Malins et al. 1987; Myers et al. 1987, 1991,1992, 1994; Myers \& Rhodes 1988) and also the cytogenetic action of certain mutagenic and carcinogenic substances on the structure of the fish genome (Carrasco et al. 1990). The results of our experiment, focused on modulation of the 7-ethoxyresorufin-O-deethylase (EROD) activity of cytochrome P4501A (CYP1A) and glutathion-dependent enzymes in the liver tissue of rainbow trout after 
21-day exposure to three major pollutants, including 2,3,7,8-tetrachlorodibenzo- $p$-dioxine, hexachlorocyclohexane and di(2-ethylhexyl)phthalate, have motivated us to use more biochemical tests focused mainly on identifying disorders in the intermediary metabolism.

The objective of the study was to describe changes in the peripheral blood of rainbow trout through selected biochemical parameters of the blood plasma. The biochemical tests were complemented by examination of the profile of protein, nitrogen, carbohydrate and mineral metabolism, activities of the major enzymes, non-specific immunity and genomic damage.

\section{Material and methods}

\section{Test chemicals}

2,3,7,8-tetrachlorodibenzo- $p$-dioxin (TCDD), belongs to lipophilic and highly persistent organic pollutants (POPs) capable of bioaccumulation through food chains. Being linked to the Ah-receptor, most of its negative impacts are connected with a number of dioxin-type toxic effects (increased level of bioactivating enzymes, particularly the CYP1A, a risky increase in cell proliferation, immunotoxic effects, oxidative stress).The natural sources of TCDD include the biosynthesis of certain precursors, manufacturing processes involving chlorination of phenols, production of 2,4,5-trichlorophenol, production of chlorophenoxyacetic acid-based pesticides, production of PCB, copper, nickel, iron and steel smelting, waste-fired power generation, residential and industrial fires, pulp bleaching, automobile traffic and large-scale application of chlorophenoxyacetic acid-based pesticides containing polychlorinated dibenzo- $p$-dioxins and dibenzofurans ( $\mathrm{PCDDs} / \mathrm{Fs}$ ) etc. Chemical effects include carcinogenicity and teratogenicity (Lenga 1988). According to Hutz et al. (2006) rainbow trout exposed to TCDD in vivo showed inhibition of oestrogen synthesis, potentially causing fertility defects. Giesy et al. (2002) reported a reduced survival of rainbow trout fry from females fed as little as $1.8 \mathrm{ng}$ TCDD per kg feed. These authors observed no effect on growth or condition for adult rainbow trout exposed to TCDD concentrations as high as $90 \mathrm{ng} \mathrm{TCDD} / \mathrm{kg}$ ww in food for up to 300 days. Biochemical, histological and behavioural aspects of visual function during the early development of rainbow trout were studied by Carvalho (2004). Hepatocellular glycogen depletion and a number of other pathological changes (increased mitosis, nuclear and cellular pleomorphism, single cell necrosis, margination and clumping of chromatin) are described by Walter et al. (2000) in adult female rainbow trout exposed dietary for $320 \mathrm{~d}$ to environmentally relevant doses of TCDD.

$\mathrm{Di}$ (2-ethylhexyl)phthalates (DEHP), are used as plasticisers in the manufacture of plastics (PVC, cellulose esters, synthetic elastomers) and to improve the mechanical properties of plastics (improve ductility, reduce brittleness). They enter the environment during production and by emanation from DEHP-containing products. In mammals it acts through what is called peroxisomal proliferation, involving increased proliferation of peroxisomes, oxidative stress and hepatocarcinogenicity (Lake 1995). Van Wezel et al. (2000) indicate environmental risk limits (ERLs) for di(n-butyl)phthalate (DBD) and DEHP. The ERLs are derived using data on ecotoxicology and environmental chemistry. The endpoints used are survival, growth, and reproduction. The resulting ERLs in water are 10 and $0.19 \mu \mathrm{g}^{-1}$ for DBD and DEHP, respectively; in fresh soil and sediment with $10 \%$ organic matter the derived ERLs are, respectively, 0.7 and $1 \mathrm{mg}$ per $\mathrm{kg}$ fresh $\mathrm{nt}$. The chronic toxicity of six phthalate esters to rainbow trout was studied by Rhodes et al. (1995). The results of ELS studies (early life stage) indicated that chronic effects were observed for dimethyl phthalate (survival) and diethyl phthalate (growth) at 24 and $0.19 \mathrm{mg} \mathrm{l}^{-1}$, respectively. This pattern of observed toxicity with the lower-molecular-weight phthalate esters and not the higher-molecular-weight phthalate esters is consistent with previously reported acute toxicity studies for several aquatic species.

Hexachlorocyclohexane $(\gamma-\mathrm{HCH})$, belongs to insecticides containing a number of hexachloro-cyclohexane isomers, among which only $\gamma-\mathrm{HCH}$ is active. It is isolated during the manufacturing process. A sufficiently pure $\gamma-\mathrm{HCH}$ is called lindane. It is a contact, fumigant and ingestion insecticide, which enters the environment with the products made on its basis. Lindane is known as a carcinogenesis promoter. According to Tierney et al. (2014), the insecticidal properties of lindane were first discovered in the 1940s. It has been widely used in agriculture for disease vector control and as a pharmaceutical treatment for lice and scabies. The acute and chronic toxicity of lindane was studied by many authors. Some of the studies were focused on the histopathological effects of pesticides and related chemicals on the livers of fishes. Early necrotic, coagulative lesions were associated with the portal triads of rainbow trout exposed to critical levels of lindane (Couch 1975). Effects of lindane on the gills of young rainbow trout were described by Nenadic \& Springer (1991). In the gills the higher concentrations ( 75 and $90 \mathrm{mg} \mathrm{l}^{-1}$ ) produces necrosis, oedema and separation of the epithelium from the underlying tissue. Epithelial hypertrophy and hyperplasia occurred with the lower concentrations. Histopathological changes in the gills are also described in other fish species. Nandan \& Nimila (2012) observed proliferation of the lamellar epithelium and lamellar fusion in Etroplus maculatus. Similar changes were 
described in Sparus aurata by Gonzáles de Canales et al. (2009), and fusion of the secondary lamella, increased raising of the branchial epithelium and intraepithelial oedema were described in the same fish by Ortiz et al. (2003). Erosion of the tips of the gill filaments in Colisa fasciatus was described by Verma et al. (1975).

\section{Experimental environment and fish}

The experiments were conducted on a trout hatchery where the fish had been kept on a long-term basis to acclimate to the chemical composition of the water and the oxygen saturation thereof. The fish were kept in fibre-glass tanks $3.6 \times 0.7 \times 0.7 \mathrm{~m}$ in size with a continuous supply of new fresh water and with a photoperiod of $16.00 \mathrm{~h}$ light: $08.00 \mathrm{~h}$ dark. Two experimental groups and two control groups were formed, each comprised of 10 fish. The experimental fish was rainbow trout, all of the same origin and weight of $115 \pm 24 \mathrm{~g}$ (mean \pm SD) and their Fulton's condition factor (body weight in $\mathrm{g} \times 100 / \mathrm{standard} \mathrm{length}^{3}$, in $\mathrm{cm}$ ) was 1.44 to 1.96 . With respect to the results of our previous works and the studies referred to above, where differences in metabolite levels were caused by sexual dimorphism, we used in our trials female fish, whose number prevailed in the biomass of farmed rainbow trout (Řehulka et al. 2004, 2005; Řehulka \& Minařík 2008, 2012). It was important in this study to ensure a steady state of health of the fish. Accordingly, the conditions specified below had to be met to ensure the absence of clinical signs of disease and of pathological and anatomic changes in the post-mortem examination (Roberts 2012) and /or bacterial examination (Austin \& Austin 2012) of the fish, and in significant parasite infections (Ergens 1992; Lom \& Dyková 1992). For 14 d prior to the start of the trial, the fish were left to adapt to the environment and during the trial they were not fed. The water had the following physical and chemical characteristics during the trial: water temperature $15-17^{\circ} \mathrm{C}$, dissolved $\mathrm{O}_{2} 8-9.5 \mathrm{mg} \mathrm{l^{-1 }}$, oxygen saturation $85-106 \%, \mathrm{pH} 6.6-6.8, \mathrm{COD}_{\mathrm{Mn}}$ (chemical oxygen demand) $9.7-9.8 \mathrm{mg} \mathrm{l}^{-1}$, ammonium $\left(\mathrm{NH}_{4}^{+}\right) 0.12$ $-0.44 \mathrm{mg} \mathrm{l}^{-1}$, nitrites $\left(\mathrm{NO}_{2}^{-}\right) 0.014-0.075 \mathrm{mg} \mathrm{l}^{-1}$, nitrates $\left(\mathrm{NO}_{3}^{-}\right) 3.9-21.5 \mathrm{mg} \mathrm{l}^{-1}$. DEHP (experimental groups EG1 and EG2), TCDD (experimental group EG3) and $\gamma-\mathrm{HCH}$ (experimental groups EG4 and EG5), dissolved in $200 \mu 1$ of dimethylsulphoxide (DMSO), were administered (upon anaesthesia of the fish) by the intraperitoneal route (i.p.) on the right side between the pectoral and pelvic fins, as shown in the scheme in Table 1. Fish in the control group (CG) were injected in the same manner with $200 \mu \mathrm{l}$ of DMSO. Exposure time and the concentration of the test material were determined according to the results of the experiment (referred to above) focused on modulation of the 7-ethoxyresorufin-O-deethylase (EROD) activity of cytochrome P4501A (CYP1A) and glutathion-dependent enzymes in the liver tissue of rainbow trout. Concentrations exceeding those occurring under natural conditions were purposefully used in our study in order to learn the effects of higher concentrations that may occur in the event of uncontrolled leakage to water courses, accidental pollution or flood. Concentration of the test material were either injected once or sequentially at intervals.

Tab 1: Oncorhynchus mykiss. Time schedule of pollutant injecting ( $\boldsymbol{\square})$ by the intraperitoneal route ( $\square$ marks the end of testing).

\begin{tabular}{|c|c|c|c|c|c|c|c|c|c|}
\hline $\begin{array}{c}\text { Experimental } \\
\text { group }\end{array}$ & $\begin{array}{c}\text { Test } \\
\text { substance }\end{array}$ & $\begin{array}{l}\text { The amount of test } \\
\text { substance per kg } \\
\text { of fish }\end{array}$ & $\begin{array}{c}1 \\
\text { day }\end{array}$ & $\begin{array}{c}4 \\
\text { day }\end{array}$ & $\begin{array}{c}8 \\
\text { day }\end{array}$ & $\begin{array}{c}10 \\
\text { day }\end{array}$ & $\begin{array}{c}16 \\
\text { day }\end{array}$ & $\begin{array}{c}21 \\
\text { day }\end{array}$ & $\begin{array}{l}28 \\
\text { day }\end{array}$ \\
\hline$\overline{\text { EG1 }}$ & $\overline{\text { DEHP }}$ & $50 \mathrm{mg}$ & - & a & - & - & - & $\square$ & \\
\hline EG2 & DEHP & $200 \mathrm{mg}$ & - & 匹 & - & - & - & $\square$ & \\
\hline EG3 & TCDD & $2 \mu \mathrm{g}$ & - & & & & & $\square$ & \\
\hline EG4 & $\gamma-\mathrm{HCH}$ & $50 \mathrm{mg}$ & घ & & & & & $\square$ & \\
\hline EG5 & $\gamma-\mathrm{HCH}$ & $5 \mathrm{mg}$ & - & & & & घ & & $\square$ \\
\hline
\end{tabular}

\section{Preparation of blood samples}

In all experiments, blood samples were collected between 08.00 and 11.00 hours. The fish were anaesthetised with Menocain (Spofa, Prague, Czech Republic) (3-amino benzoic acid sodium hydrogen sulphate ethyl ester) at a concentration of $0.06 \mathrm{~g} \mathrm{l}^{-1}$ (Král 1988) and then samples were taken by puncturing the caudal vessels. Sodium heparin (5000 IU in a $1 \mathrm{ml}$ injection) drawn through the syringe was used as anticoagulant. The blood plasma was obtained by centrifuging the blood at $4100 \mathrm{~g}$ for $10 \mathrm{~min}$ at $4^{\circ} \mathrm{C}$; then the blood was separated into plastic syringes and was transported at a temperature of $4^{\circ} \mathrm{C}$ to laboratory for analysis.

\section{Clinical chemistry}

A Hitachi 717 multiparametric analyser (Tokyo, Japan) was used for the determinations: total protein (TP, in $\mathrm{g}^{-1}$ ), blood urea nitrogen (BUN, in $\mathrm{mmol}^{-1}$ ), uric acid (UA, in $\mu \mathrm{mol} \mathrm{l}^{-1}$ ), creatinine $\left(\mathrm{CREA}\right.$, in $\left.\mu \mathrm{mol} \mathrm{l}^{-1}\right)$, glucose $\left(\mathrm{GL}\right.$, in $\left.\mathrm{mmol} \mathrm{l}^{-1}\right)$, inorganic phosphate $\left(\mathrm{P}\right.$, in $\left.\mathrm{mmol} \mathrm{l}^{-1}\right)$, total calcium $\left(\mathrm{Ca}_{t}\right.$, in mmol $\left.\mathrm{l}^{-1}\right)$, alanine 
aminotransferase (ALT, in $\mu \mathrm{kat}^{-1}$ ), aspartate aminotransferase (AST, in $\mu \mathrm{kat} \mathrm{l}^{-1}$ ), alkaline phosphatase (ALP, in $\mu$ kat $1^{-1}$ ) and lactate dehydrogenase (LD, in $\mu$ kat $1^{-1}$ ). Kits produced by PLIVA-Lachema, a.s. Brno, Czech Republic, and DIALAB Wien, Austria, and Prague, Czech Republic, were used for the determination of all indices.

\section{Haematology}

Blood smears were air-dried and stained by the May-Grünwald and Giemsa Romanowski methods. The leucocytes were differentiated according to Ivanova (1983). Next the same smears were stained according to the periodic acid - Shiff method and Sudan Black B method to identify granulocytes. The relative abundance of all cell types was determined by counting a total of 200 white blood cells per smear.

\section{Genotoxicity}

Piscine micronucleus test (MNT) (Hoftman \& de Raat 1982) determining the frequencies of micronucleated red blood cells per 1000 cells was used to prove genomic damage.

\section{Sampling procedure for histopathology}

For histological examination, tissue samples of liver and kidney were fixed in $10 \%$ neutral formalin and the paraffin slices were stained with haematoxylin and eosin by the PAS method (periodic acid Schiff's reagent) and were tested for demonstration of bile pigments (Stein).

\section{Statistical analysis}

Data from the injected and control fish were compared, using the $F$ test and $t$ test. For graphic processing we preferred to use the notch box graphs with filaments, as they complement statistical characteristics in Table 2 and, in particular, give a graphic idea of how the values for the analyses under study are positioned in the experimental and control fish. All the calculations were made using the UNISTAT $^{\circledR}$ (2011) statistical package for MS Windows ${ }^{\text {TM }}$

\section{Results}

\section{Clinical symptoms, biochemistry and histopathology \\ DEHP}

An increase in the level of $\mathrm{P}$ and decrease in $\mathrm{Ca}_{t}$, and lower catalytic concentrations of ALT and ALP, were recorded in both experimental groups.

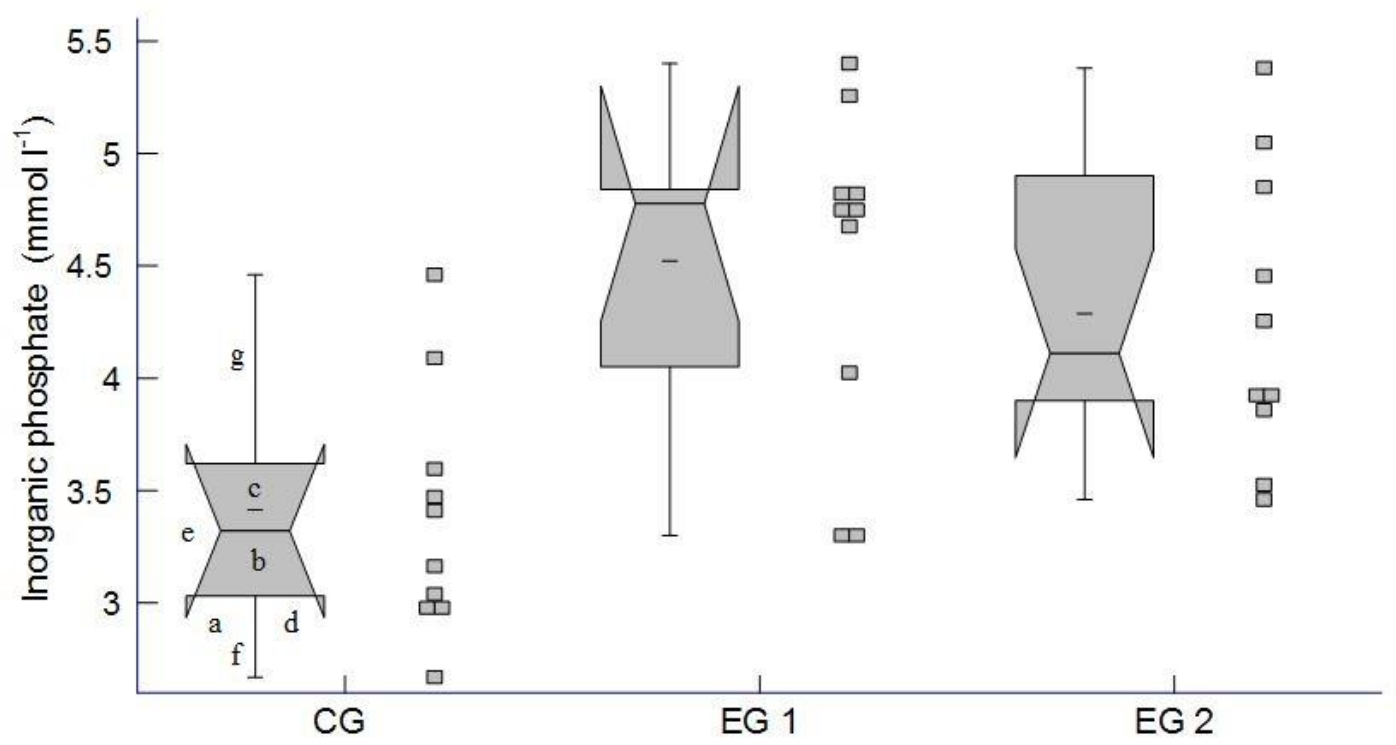

Fig 1. 


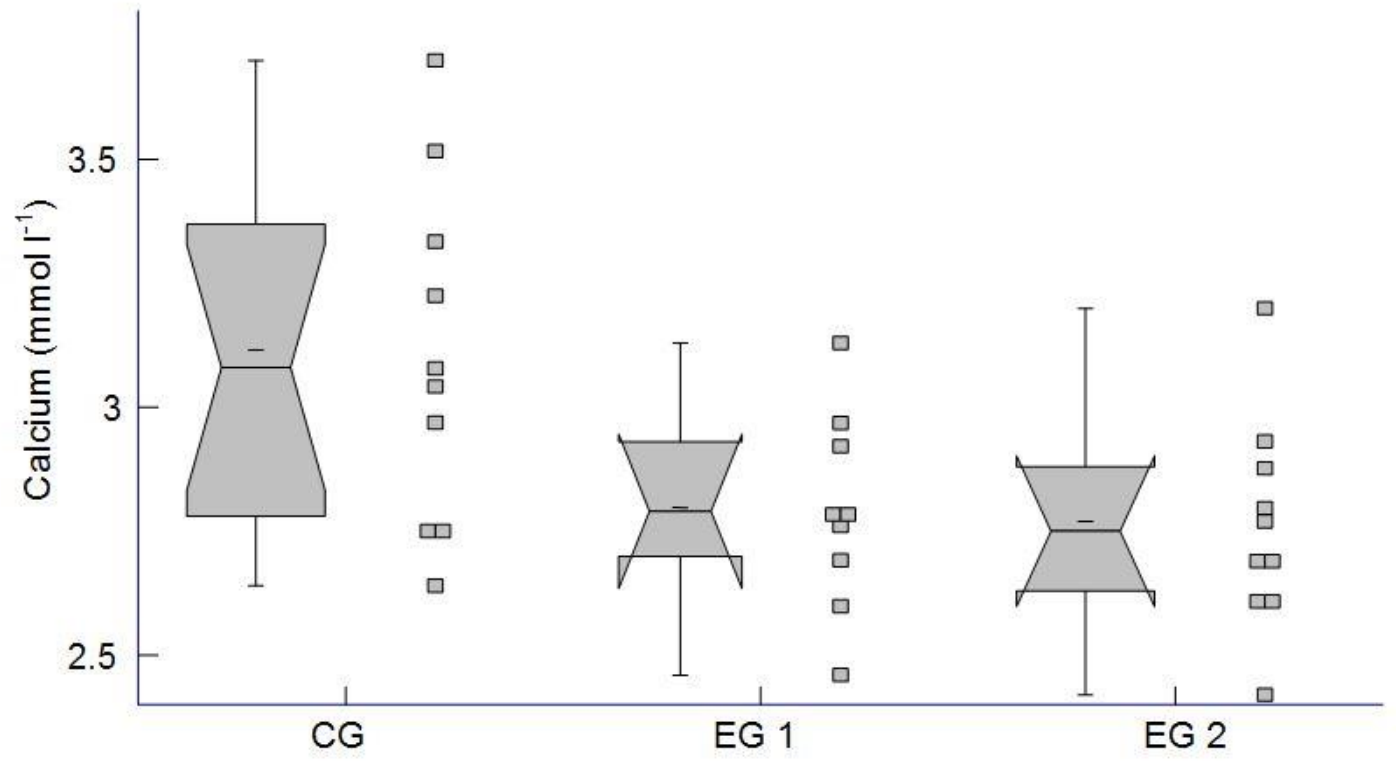

Fig 2.

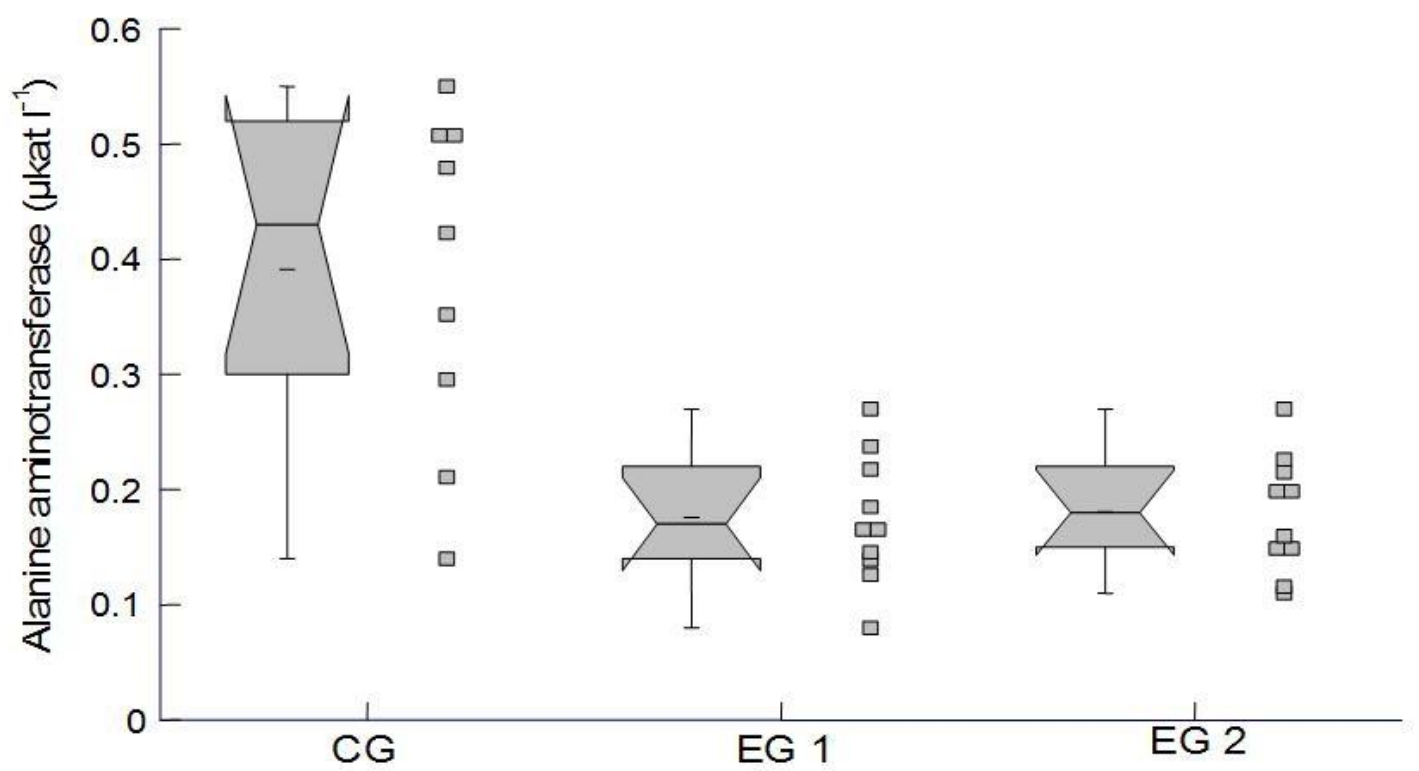

Fig 3. 


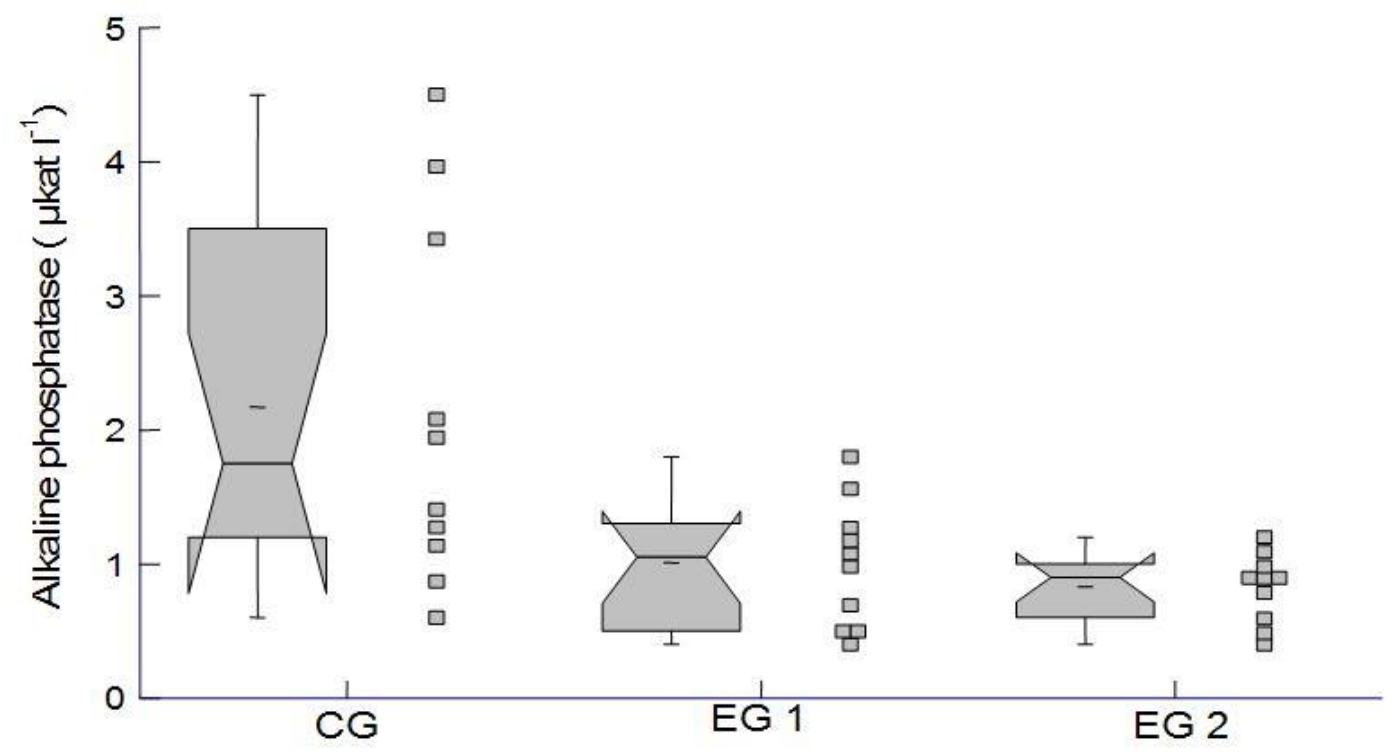

Fig 4.

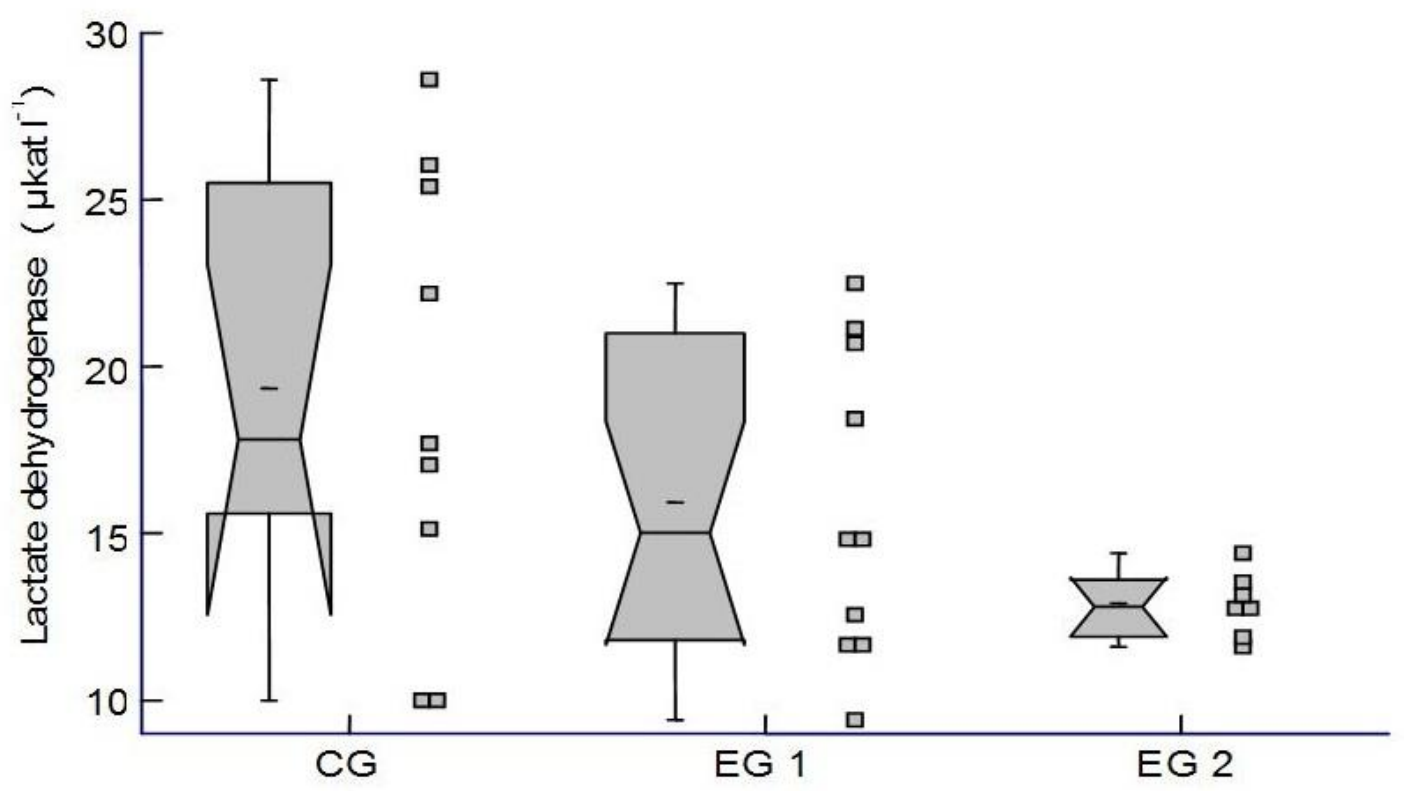

Fig 5. 


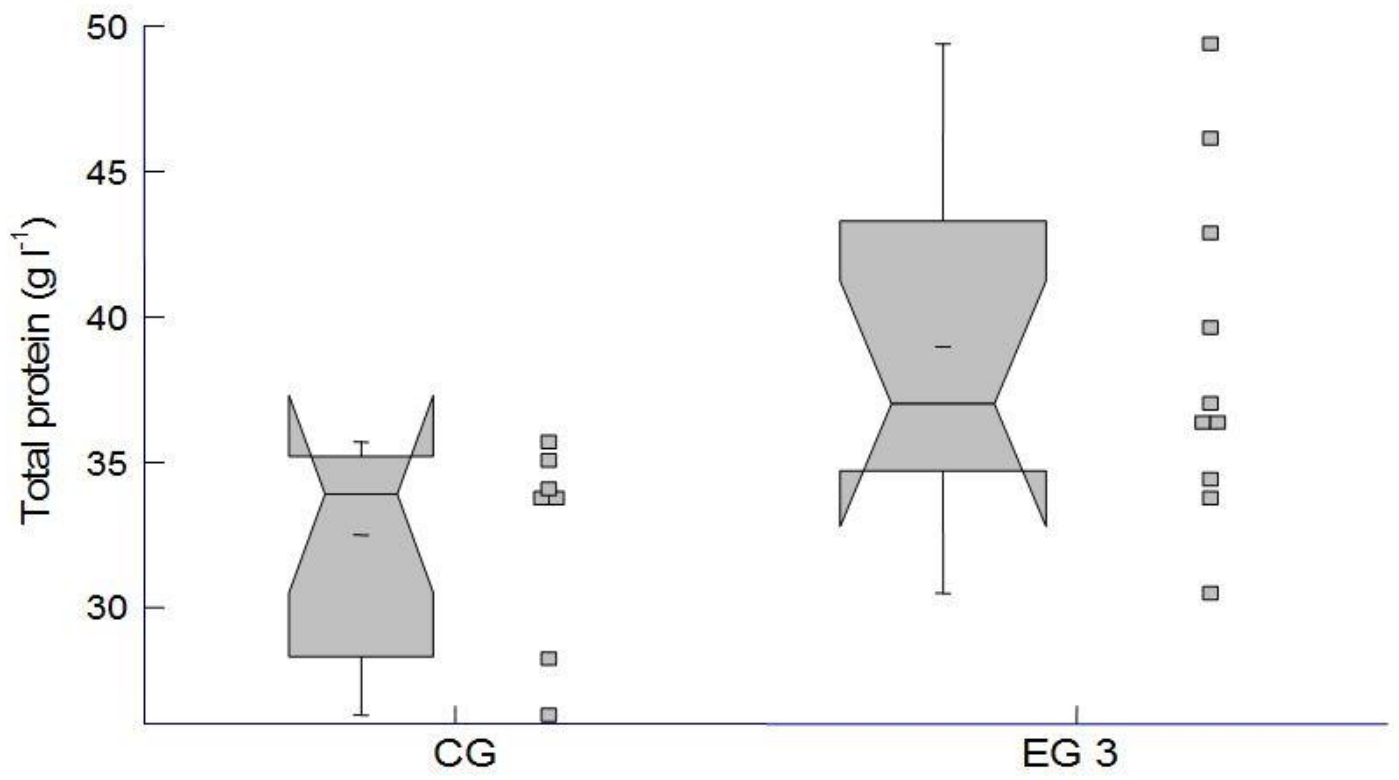

Fig 6.

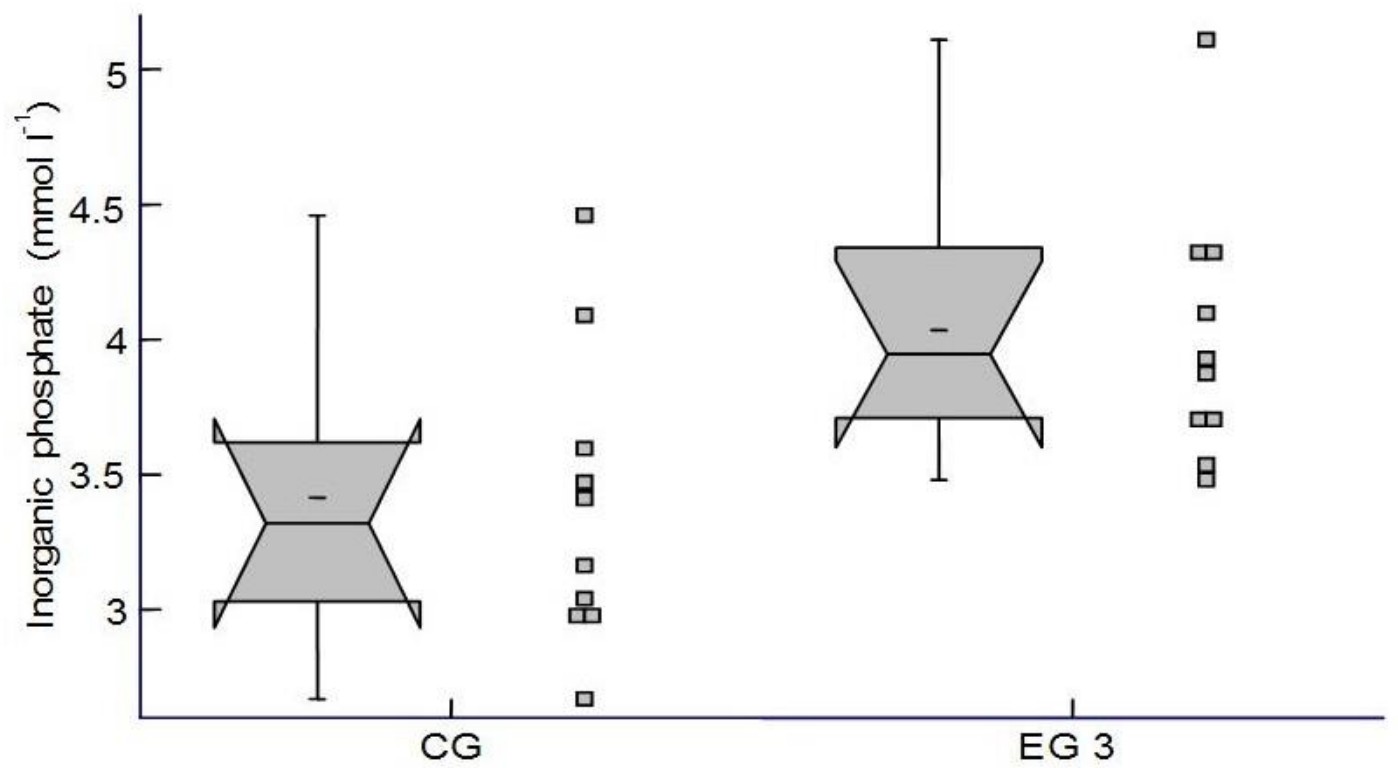

Fig 7. 


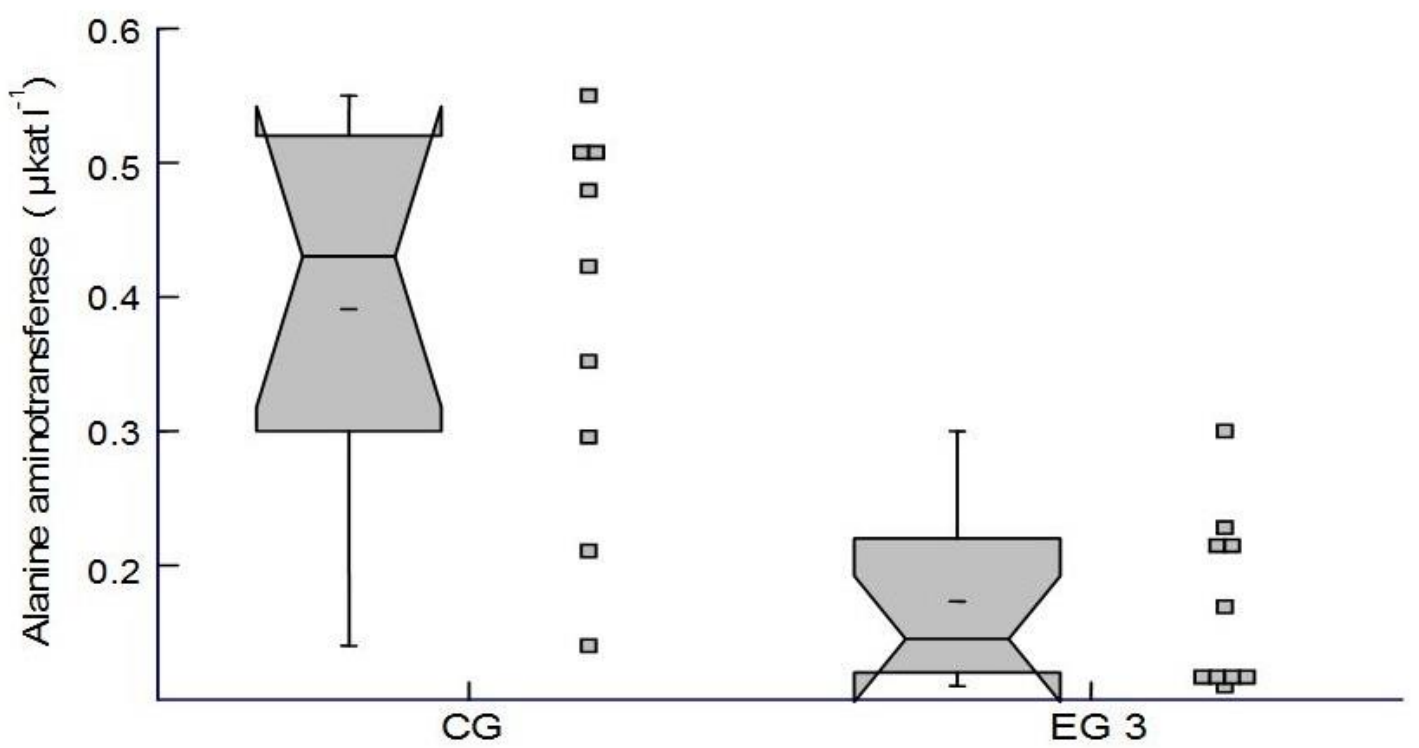

Fig 8.

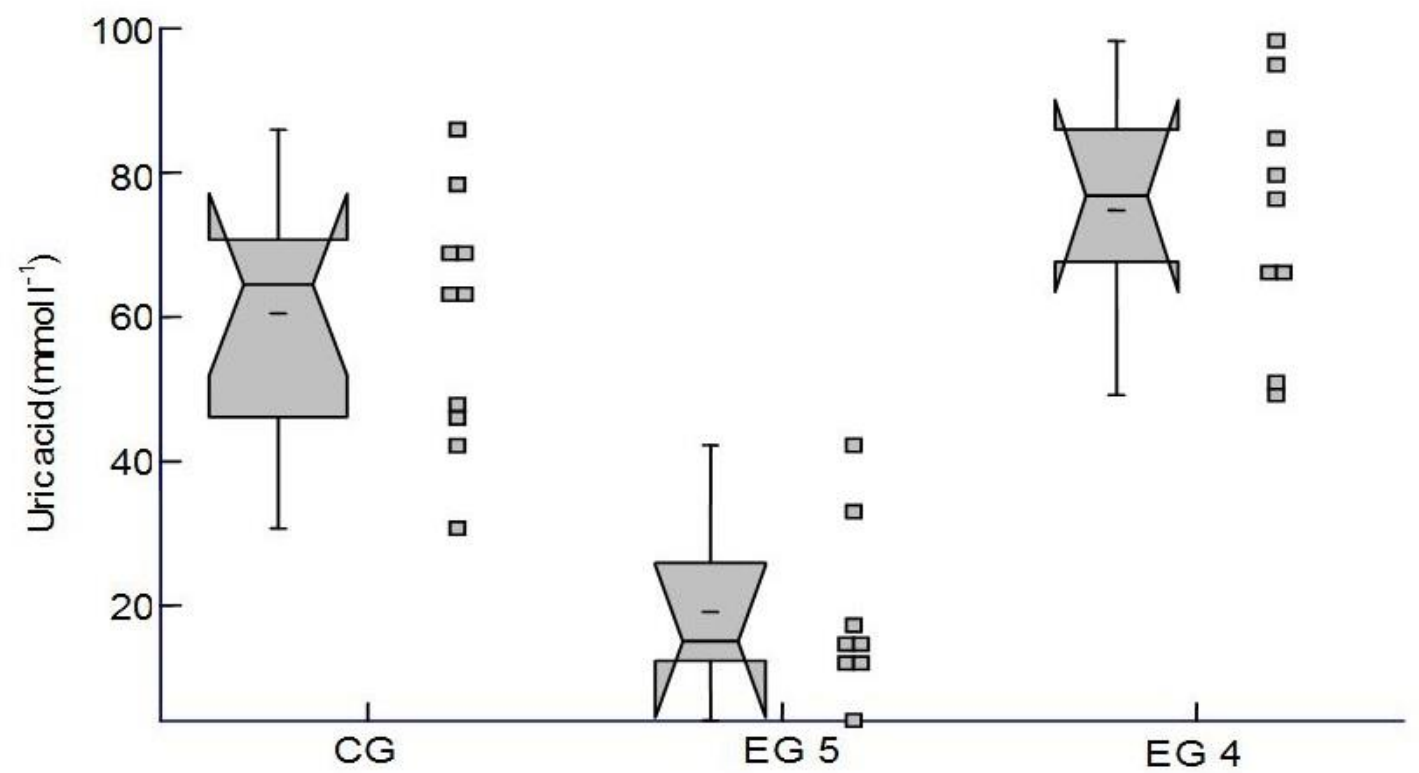

Fig 9. 


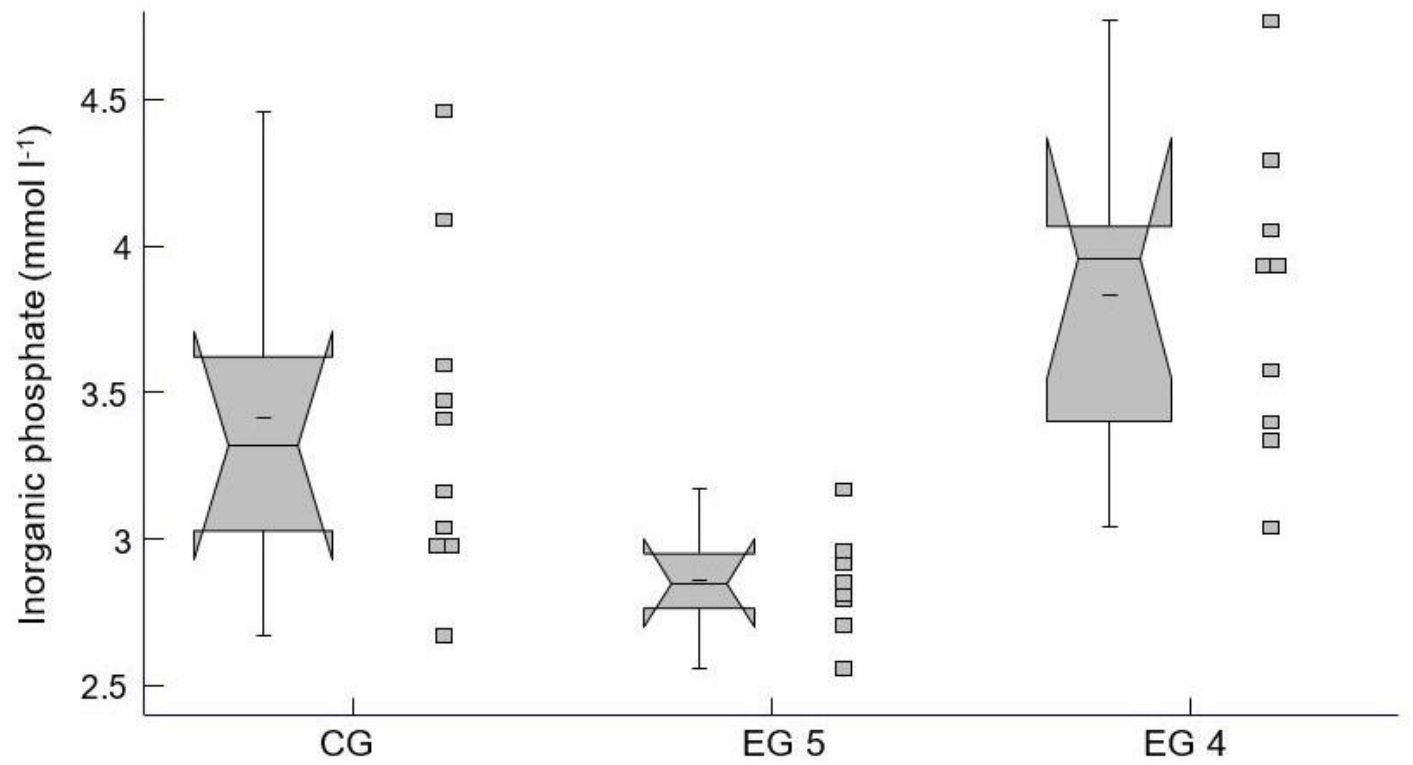

Fig 10

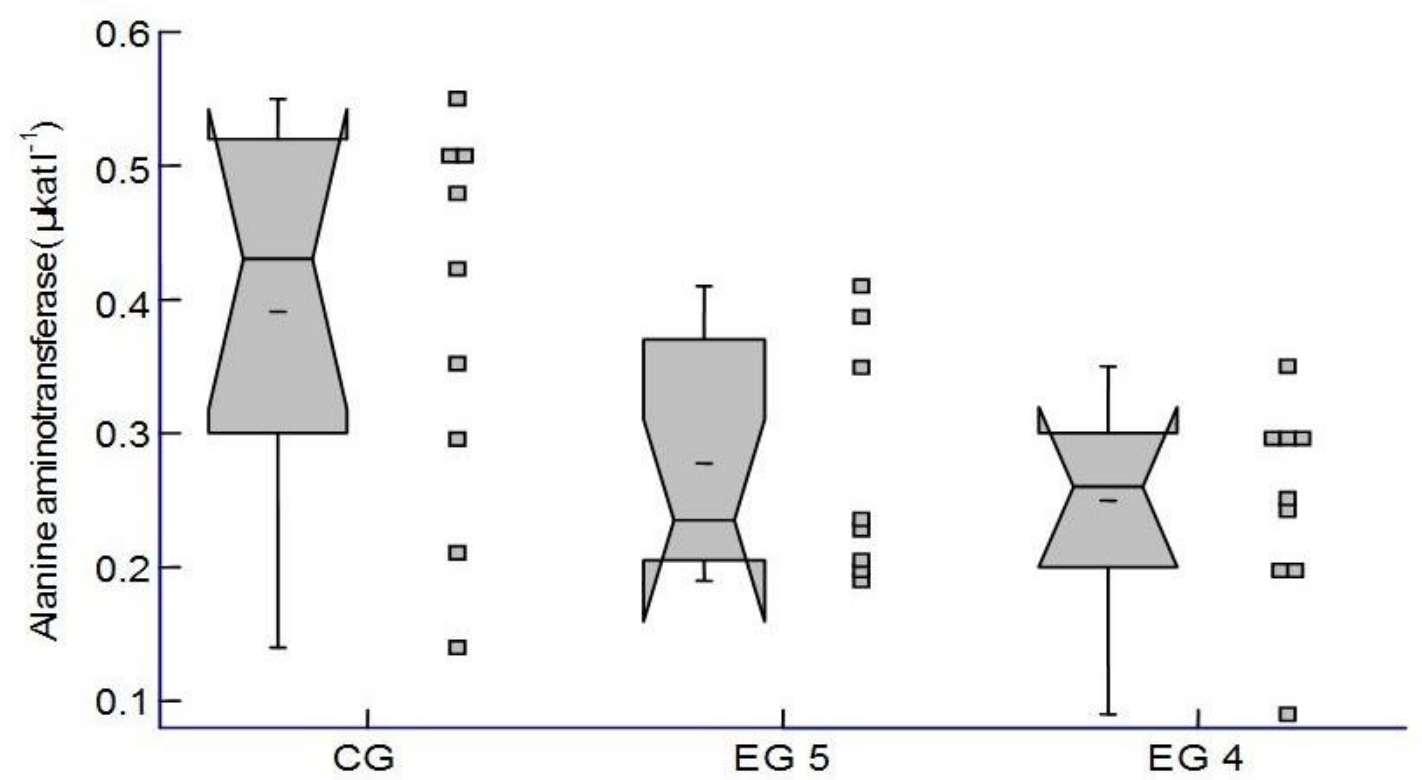

Fig 11 


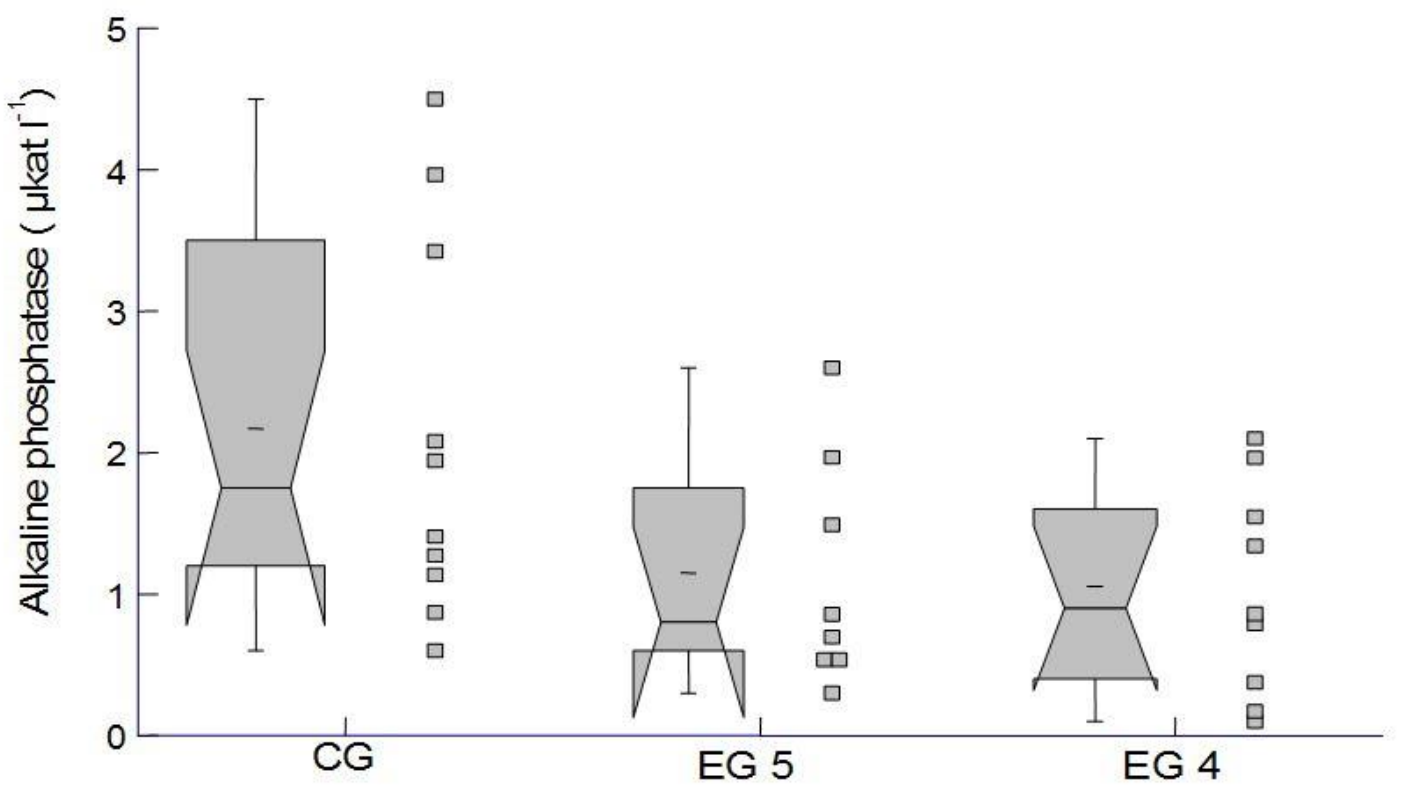

Fig 12

Figs 1-12: Oncorhynchus mykiss. Biochemical values in experimental and control rainbow trout offered by notch box graphs with filaments:

$\mathbf{a}=$ width of the box, indicating the size of the set; $\mathbf{b}=$ mid-diagonal of the box, representing the position of the median in relation to the $\mathrm{y}$ axis; $\mathbf{c}=$ mark inside the box, showing the position of the arithmetic mean; $\mathbf{d}=$ lower and upper edge of the box, indicating successively the position of the lower and upper quartiles; $\mathbf{e}=$ width of the notch, corresponding to the confidence interval around the median; $\mathbf{f}=$ the lower filament, with a length corresponding to the value of the lower quartile reduced by $1.5 \times$ the span of the quartiles. If this value is lower than the minimum value in the set, the length of the filament corresponds to this minimum value. If values lower than those corresponding to the coordinate of the end point of the lower filament do occur in the set, then these values are signalled as remote; $\mathbf{g}=$ the upper filament, with a length corresponding to the value of the upper quartile enlarged by $1.5 \times$ the span of the quartiles. If this value is higher than the maximum value in the set the length of the filament corresponds to this maximum value. If values higher than those corresponding to the coordinate of the end point of the upper filament do occur in the set, then these values are signalled as remote.

The catalytic concentration of AST was lower in EG1 and a reduced catalytic concentration of LD was in EG2 (Fig. 5). Comparisons between the two experimental groups showed a significant $(p \leq 0.05)$ increase in the catalytic concentration of AST in EG2 (4.76 - 5.93 [EG2] vs $1.2-6.77$ [EG1]) (Table 2). 
Tab 2: Oncorhynchus mykiss. Comparison of biochemical parameters of control rainbow trout (CG) injected with DMSO and fish injected with 50 mg kg ${ }^{-1}$ di(2ethylhexyl)phthalate (DEHP) (EG 1), $200 \mathrm{mg} \mathrm{kg}^{-1}$ DEHP (EG 2), $2 \mu \mathrm{g} \mathrm{kg}^{-1}$ 2,3,7,8-tetrachlorodibenzo-p-dioxine (TCDD) (EG 3), 50 mg kg ${ }^{-1}$ hexachlorocyclohexane $(\gamma-\mathrm{HCH})(\mathrm{EG} 4)$ and $5 \mathrm{mg} \mathrm{kg}^{-1} \gamma-\mathrm{HCH}(\mathrm{EG} 5)$. Mean \pm standard deviation; * probability.

\begin{tabular}{|c|c|c|c|c|c|c|c|c|c|c|c|}
\hline Test & CG & EG 1 & $t$ test & EG 2 & $t$ test & EG 3 & $t$ test & EG 4 & $t$ test & EG 5 & $t$ test \\
\hline TP $\mathrm{g}^{-1}$ & $32.5 \pm 3.66$ & $31.8 \pm 6.42$ & 0.805 & $31.3 \pm 5.4$ & 0.621 & $38.9 \pm 5.89$ & $0.022^{*}$ & $37.8 \pm 11.49$ & 0.247 & $29.7 \pm 4.21$ & 0.202 \\
\hline BUN mmol $1^{-1}$ & $0.4 \pm 0.17$ & $0.5 \pm 0.19$ & 0.363 & $0.5 \pm 0.12$ & 0.558 & $0.3 \pm 0.1$ & 0.132 & $0.5 \pm 0.21$ & 0.692 & $0.3 \pm 0.12$ & 0.115 \\
\hline $\mathrm{UA} \mu \mathrm{mol} 1^{-1}$ & $60.5 \pm 17.63$ & $65.1 \pm 13.72$ & 0.523 & $58.7 \pm 13.14$ & 0.791 & $60.5 \pm 16.2$ & 1 & $74.7 \pm 17.3$ & 0.094 & $19.1 \pm 12.6$ & $0.000^{*}$ \\
\hline CREA $\mu \mathrm{mol} 1^{-1}$ & $13.8 \pm 8.4$ & $12.4 \pm 3.73$ & 0.616 & & & $15.2 \pm 5.8$ & 0.134 & $16.1 \pm 6.69$ & 0.531 & $17.5 \pm 5.57$ & 0.311 \\
\hline GL $\mathrm{mmol} \mathrm{l}^{-1}$ & $4.79 \pm 0.86$ & $4.41 \pm 0.87$ & 0.340 & $4.45 \pm 0.72$ & 0.346 & $5.28 \pm 0.36$ & 0.127 & $3.97 \pm 0.49$ & 0.184 & $5.45 \pm 1.18$ & 0.184 \\
\hline $\mathrm{P} \mathrm{mmol} \mathrm{l}^{-1}$ & $3.41 \pm 0.54$ & $4.52 \pm 0.73$ & $0.001^{*}$ & $4.29 \pm 0.64$ & $0.004^{*}$ & $4.04 \pm 0.48$ & $0.014^{*}$ & $3.83 \pm 0.53$ & 0.108 & $2.86 \pm 0.18$ & $0.011^{*}$ \\
\hline $\mathrm{Ca}_{t} \mathrm{mmoll}^{-1}$ & $3.12 \pm 0.34$ & $2.8 \pm 0.2$ & $0.028^{*}$ & $2.77 \pm 0.21$ & $0.015^{*}$ & $3 \pm 0.17$ & 0.36 & $2.83 \pm 0.4$ & 0.116 & $2.83 \pm 0.22$ & 0.063 \\
\hline 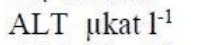 & $0.39 \pm 0.14$ & $0.18 \pm 0.05$ & $0.002^{*}$ & $0.18 \pm 0.05$ & $0.002^{*}$ & $0.17 \pm 0.06$ & $0.002^{*}$ & $0.25 \pm 0.07$ & $0.024^{*}$ & $0.28 \pm 0.09$ & 0.077 \\
\hline AST $\mu$ kat $^{-1}$ & $6.78 \pm 2.88$ & $3.69 \pm 1.82$ & $0.015^{*}$ & $5.45 \pm 0.43$ & 0.207 & $7.32 \pm 0.71$ & 0.601 & $6.5 \pm 3.76$ & 0.865 & $4.29 \pm 2.16$ & 0.065 \\
\hline ALP $\mu \mathrm{kat} \mathrm{l}^{-1}$ & $2.17 \pm 1.35$ & $1.01 \pm 0.48$ & $0.027^{*}$ & $0.83 \pm 0.25$ & $0.012^{*}$ & $1.77 \pm 0.86$ & 0.442 & $1.06 \pm 0.75$ & $0.044^{*}$ & $1.15 \pm 0.8$ & 0.080 \\
\hline $\mathrm{LD} \mu \mathrm{kat}^{-1}$ & $19.34 \pm 6.83$ & $15.93 \pm 4.68$ & 0.217 & $12.9 \pm 0.96$ & $0.022^{*}$ & $19.89 \pm 7.18$ & 0.868 & $16.81 \pm 6.58$ & 0.450 & $13.63 \pm 4.15$ & 0.072 \\
\hline
\end{tabular}

TP: total protein; BUN: blood urea nitrogen; UA: uric acid; CREA: creatinine; GL: glucose; P: inorganic phosphate; Ca $a_{t}$ total calcium; ALT: alanine aminotransferase; AST: aspartate aminotransferase; ALP: alkaline phosphatase; LD: lactate dehydrogenase 
The post-mortem examination of the fish showed a slight accumulation of a serous fluid in the peritoneal cavity in the majority of fish in EG1 and ascites in one fish in EG2.

Histological examination revealed eosinophilic droplets in the epithelium of renal tubules and small variability of fat vacuoles of hepatocytes, especially in EG2 fish.

\section{TCDD}

The biochemical profile of this highly persistent organic pollutant, has markedly increased TP and P levels (Fig. 6 and 7) and doubly decreased ALT activity (Fig. 8).

\section{$\gamma-\mathrm{HCH}$}

Fish in EG5 had much lower levels of UA and P (Fig. 9 and 10) and fish in EG4 had a decreased catalytic concentration of ALT and ALP (Fig. 11 and 12). Significant differences (p $\leq 0.05$ ) between the experimental groups (Table 2) were observed in the rate of increase in glycaemia (3.36 - 4.69 [EG5] vs 3.67 - 7.36 [EG4]) and phosphoraemia (2.56 - 3.17 [EG5] vs $3.04-4.77$ [EG4]), and there was a tendency towards hyperuricaemia (4.09- 42.2 [EG5] vs $49.2-98.3$ [EG4] in fish injected with a higher concentration of $\gamma-\mathrm{HCH}$.

Marked post mortem changes occurred mainly in fish from EG4, which showed different levels of ascites accompanied in $50 \%$ of the fish by hyperaemia on the pyloric caeca and in visceral fat. Enlarged kidney and liver were observed in two cases in fish from EG5.

In EG4 one fish died after 18 days and in EG5 two fish died after 19 days with signs of exophthalmos and a with a large quantity of clear or turbid fluid in the abdominal cavity. There was an intensive hyperaemic demarcation around the point of injection.

Histological examination of the fish injected with $\gamma-\mathrm{HCH}$ at a higher concentration revealed an increased activation of sinusoidal cells in the liver, a fibrous thickening of bile duct walls and a periductal inflammatory cellulisation (Fig. 13a and b). The inflammation infiltrate was well bounded and patches of oedematous seepage were observed around the bile ducts with the presence of inflammatory cells in the thin connective tissue. There were no regressive changes in hepatocytes.

The parasitological and bacteriological examination of the fish at the end of the experiment was negative.

\section{Haematological and genotoxic tests}

Erythrocyte polychromasia was observed in $20 \%$ to $50 \%$ of the fish in both experimental groups injected with $\gamma-\mathrm{HCH}$. The significant $(\mathrm{p} \leq 0.01)$ increase in polychromatophilic erythrocytes was up to 0.35 , compared to 0.04 in the $\mathrm{CG}$ fish.

A significant $(\mathrm{p} \leq 0.01)$ neutrophilic leucocytosis was a typical feature of the DEHP- and TCDD-injected fish, with a highly increased occurrence of metamyelocytes, compared to the CG fish (0.13 [EG2], 0.18 [EG1] vs 0.01 [CG]) and myelocytes (0.09 [EG3] vs 0.01[CG]). A significant increase in the segmented forms was recorded in the fish from EG3 (0.03) and EG5 (0.03) vs CG 0.01). Compared to the CG fish (0.95), the proportion of lymphocytes was 0.84 in the fish from EG2, 0.76 in the fish from EG1 and 0.88 in the fish from EG3.

The occurrence of micronuclei in all experimental groups as well as the control group ranged between 0.8 and $2.1 \%$ (Table 3 ). 

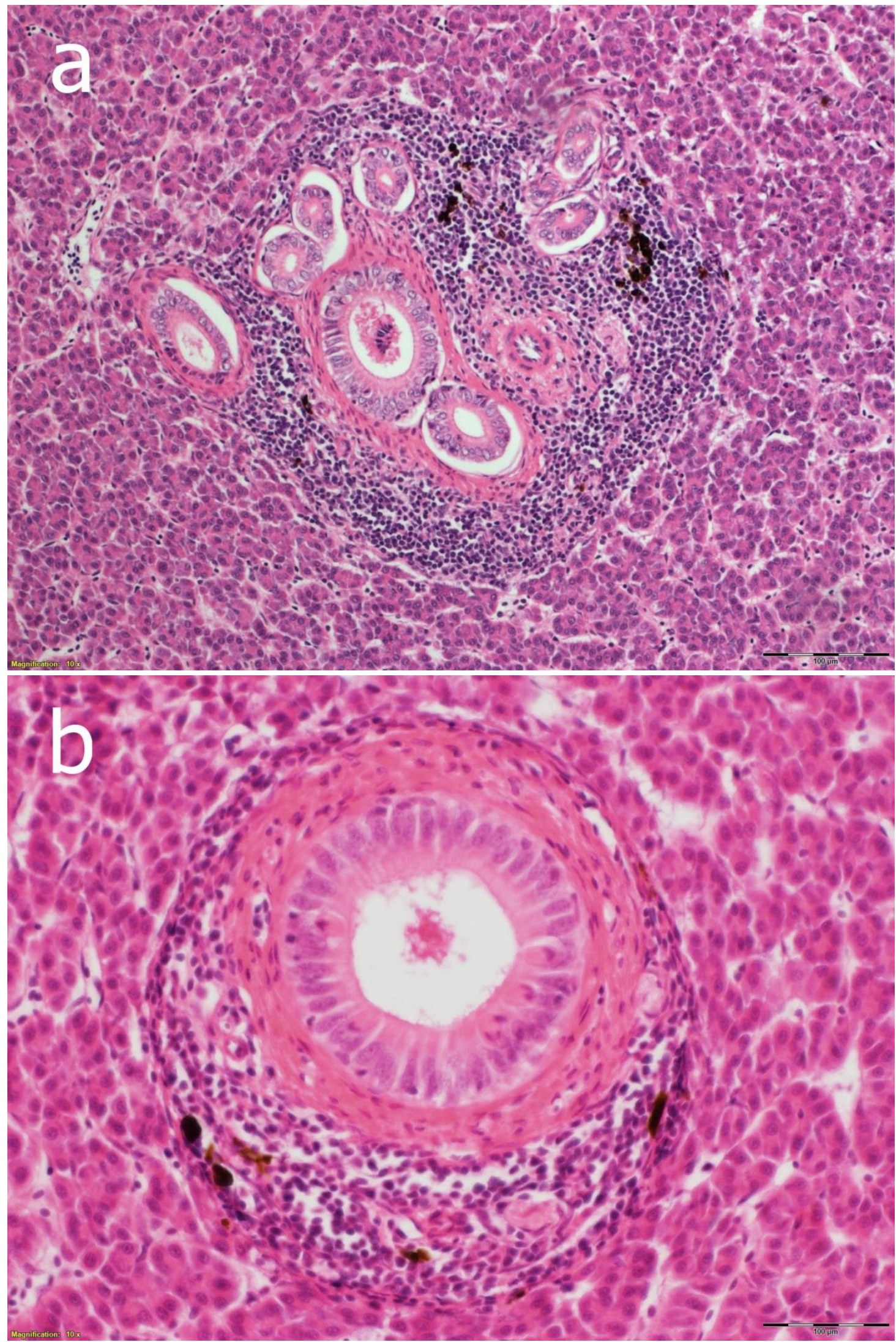

Figs 13a,b: Oncorhynchus mykiss. Cholangitis. (a) Bile duct hyperplasia with associated influx of inflammatory cells. (b) Bile duct showing mild influx of inflammatory cells. 
Tab 3: Oncorhynchus mykiss. The number of micronuclei per 1000 erythrocytes in individual rainbow trout

\begin{tabular}{cccccccc}
\hline & & \multicolumn{5}{c}{ Experimental group } & \\
& CG & EG1 & EG2 & EG3 & EG4 & EG5 \\
\cline { 2 - 7 } & 10 & 10 & 10 & 1 & 10 & 9 & 8 \\
\hline Individual & 2 & 5 & 1 & 0 & 2 & 3 \\
fish & 4 & 1 & 1 & 1 & 1 & 1 \\
& 2 & 0 & 1 & 2 & 1 & 2 \\
& 1 & 3 & 0 & 1 & 0 & 0 \\
& 3 & 4 & 0 & 1 & 1 & 4 \\
& 1 & 1 & 1 & 1 & 1 & 1 \\
& 1 & 2 & 1 & 1 & 2 & 0 \\
Mean (\%) & 1 & 1 & 2 & 1 & 1 & 2 \\
\cline { 2 - 7 } & 1 & 1 & 1 & 0 & 3 & \\
\hline
\end{tabular}

\section{Discussion and conclusions}

As to the results of the analytes used, their major parameters are discussed below. These include, in the case of DEHP testing, the impact on mineral metabolism, manifesting itself as an increase in the level of $\mathrm{P}$ and decrease in the concentration of $\mathrm{Ca}_{t}$; and as for enzyme activities, we focus on the reduction of the catalytic concentrations of both aminotransferases, ALP and LD. To explain the mechanism of the occurrence of $\gamma-\mathrm{HCH}$-induced hypouricaemia, we would like to draw attention to the impact of this gamma isomer of $\mathrm{HCH}$ on reduced UA production or on the reduction of UA reabsorption in the distal tubule, or on the reduction of the tubular secretion of UA, as known in homoeothermic vertebrates given uricosurics (Racek 1999). $\gamma-\mathrm{HCH}$, like DEHP, reduced the catalytic concentration of ALT and ALP, while having a reverse impact on the level of $\mathrm{P}$.

Hyperproteinaemia in TCDD could be caused by glucocorticoids, particularly cortisol, affecting the metabolism of proteins (Smith 1991).

It is remarkable that all the tested pollutants left the level of GL unchanged, although many authors assert that an increased GL level in blood plasma is a response of the fish to acute toxicity of pollutants (Svobodová 1971; Srivastava 1981; Singh \& Srivastava 1982; Mishra \& Srivastava 1983; Natarajan 1989), including organophosphates (Gill et al. 1990; Balint et al. 1995; Sancho et al. 1997; Ceron et al.1997; Lusková et al. 2002). It is of course possible that GL might vary significantly in other periods of the experiment.

Significant differences in GL levels were only observed between the two tested concentrations of $\gamma-\mathrm{HCH}$ ( 5 or $50 \mathrm{mg} \mathrm{kg}^{-1}$ ). Mourad et al. (1999) demonstrated this in their trials where Tilapia zillii were subjected to sub-lethal lindane concentrations of 10 and $20 \mathrm{mg}$ $1^{-1}$. GL level decreased after 3, 6 and $24 \mathrm{hr}$, whereas hyperglycaemia was noticed after 48, 96 and $168 \mathrm{hr}$ of exposure. Effects of an acute exposure to lindane on the liver carbohydrate metabolism of rainbow trout exposed to lindane at 0 or $0.05 \mathrm{mg} \mathrm{l}^{-1}$ were examined by Soengas et al. (1997). A significant increase in plasma glucose was observed in the treated fish, compared to the control after $6-12 \mathrm{hr}$.

All the tested pollutants affected the metabolism of $\mathrm{P}$ and, in particular, all suppressed the catalytic activities of the enzymes under study. The increase in the level of plasma phosphate may be due to its release from the destroyed skeleton. The lower activity of transaminase may also be due to a disorder in amino acid metabolism. An increased phosphataemia (7.46 \pm 0.243 vs $6.5 \pm 0.094$ ) was also recorded when testing a technical mixture of Delor 103 ( 
$0.24 \mathrm{mg} \mathrm{kg}^{-1}$ had, after five days of exposure, an effect similar to that observed in the blood serum in chicks after oral administration of trichlorobiphenyl Delor 103 at concentrations of 5, 50 and $100 \mathrm{mg} \mathrm{kg}^{-1}$ (Lopuchovský 1986).

Similar results in the differential leucocyte count were obtained in rainbow trout after two months of exposure to phenol at a concentration of $2 \mathrm{mg}^{-1}$ (Własow 1985) and in carp during pesticide toxicity testing (Svobodová \& Pečená 1988).

The $\gamma-\mathrm{HCH}$ concentrations tested by us did not cause histological alterations in the fish liver, as are described for pesticides, especially not those described by Gonzáles de Canales et al. (2009), who tested the toxicity of lindane to Sparus aurata exposed to $16 \mu \mathrm{g} 1^{-1}$ for 15 days (fatty degeneration and vacuolisation), or by Ortiz et al. (2003) who tested toxicity to Mugil sp., Cyprinus carpio and Barbus sp. after an accidental discharge of lindane into the Barbate River (Cádiz, SW Spain) (the hepatic cells appeared compactly arranged with a strong cytoplasmic vacuolisation [steatosis] and an increased basophilia within the cytoplasm of some hepatocytes, hepatocellular necrosis with parenchymal vacuolisation, hypertrophy of hepatocytes, haemorrhages and widening of blood sinusoids), and also Braunbeck et al. (1990), who observed hepatic steatosis in zebra fish Brachydanio rerio induced by long-term exposure to $\gamma-\mathrm{HCH}$. However, we should also pay attention to the histopathological changes in the gallblader of Catla catla treated with $1.2 \%$ lindane for 30 days, as described by Tripathi et al. (2012) (crystallization of bile and deformities in the normal structures of epithelial lining and muscular layer).

Eosinophilic droplets have also been noted in salmonids by some authors in association with toxicants (Fergusson 2006).

Our results suggest that, in addition to detecting the environmental exposure to pollutants by measuring the activities of liver detoxification enzymes, including cytochrome P4501A (CYP1A), glutathion-dependent enzymes and UDP-glucuronosyltranspherase, it is helpful also to study metabolic changes. Learning metabolic disorders by using multiple tests also indicates that it would be useful to study certain metabolites' regulatory mechanisms, as demonstrated in the case of phosphoraemia, calcaemia and glycaemia. The findings obtained when examining carbohydrate metabolism provide evidence that there are good reasons for measuring GL dynamics during trials. For a basic indication aimed at confirming the disorders of osseous metabolism, it will be necessary to test repeatedly the variation in the levels of $\mathrm{P}$ and $\mathrm{Ca}_{t}$. The results of testing the activities of both transaminases together with the pathological finding in the kidney provide an impulse for analysing the amino acid spectrum. The results of mineral metabolism, especially $\mathrm{P}$, suggest that the role of catalytic concentration of ALP as an indicator of skeleton disorders should be reviewed. Both concentrations of DEHP suggest that MNT should be used to review mutagenic risks.

Acknowledgements: This work was financially supported by the Ministry of Culture of the Czech Republic by institutional financing of long-term conceptual development of the research institution (the Silesian Museum, MK000100595), internal grant of the Silesian Museum No. IGS 201402/2014, 201506/2015.

\section{References}

Austin B. \& Austin D.A. (2012): Bacterial fish Pathogens: Disease of Farmed and Wild Fish. Fifth Edition. Springer Dordrecht Heidelberg New York London, $652 \mathrm{pp}$.

Balint T., Szegletes T., Szegletes Z., Halasy K. \& Nemcsok J. (1995): Biochemical and subcellular changes in carp exposed to the organophosphorous methidation and the pyrethroid deltamethrin. - Aquatic Toxicology 33: 279-295.

Braunbeck T., Görge G., Storch V. \& Nagel R. (1990): Hepatic steatosis in zebrafish (Brachydanio rerio) induced by long-term exposure to $\gamma$-hexachlorocyclohexane. - Ecotoxicology and Environmental Safety 19: $355-374$ 
Binder R.J. \& Stegeman J.J. (1984): Microsomal electron transport and xenobiotic monooxygenase activities during the embryonic period of development in killifish, Fundulus heteroclitus. - Toxicology and Applied Pharmacology 73: 432-443.

Buhler R.D. \& Williams D.E. (1988): The role of biotransformation in the toxicity of the chemicals. Aquatic Toxicology 11: 19-28.

Carrasco K.R., Tilbury K.L. \& Myers M.S. (1990): Assessment of the piscine micronucleus test as in situ biological indicator of chemical contaminant effects. - Canadian Journal of Fisheries and Aquatic Sciences 47: 2123-2136.

Carvalho P.S.M., Noltie D.B. \& Tillitt D.E. (2004): Biochemical, histological and behavioural aspects of visual function during early development of rainbow trout. - Journal of Fish Biology 64: 833-850.

Ceron J.J., Sancho E., Ferrando M.D., Gutierrez C. \& Andreu E. (1997): Changes in carbohydrate metabolism in the eel Anguilla anguilla, during short-term exposure to diazinon. - Toxicology and Environmental Chemistry 60: 201-210.

Couch J.A. (1975): Histopathological effects of pesticides and related chemicals on the livers of fishes. In: Ribelin W.E. \& Migaki G. (eds): The Pathology of Fishes. The University of Wisconsin Press, Madison: 559-584.

Ergens R. (1992): Gyrodactylus bohemicus sp.n. (Monogenea: Gyrodactylidae) from Oncorhynchus mykiss (Walbaum) and Salvelinus fontinalis (Mitchill) (Clupeiformes: Salmonidae) in Czechoslovakia. - Folia Parasitologica 39: 391-394.

Fergusson H.W. (ed.) (2006): Systemic Pathology of Fish: a text and atlas of normal tissues in teleosts and their responses in disease. Second Edition, Scotian Press, 367 pp.

Giesy J.P., Jones P.D., Kannan K., Newsted J.L., Tillitt D.E. \& Williams L.L. (2002): Effects of chronic dietary exposure to environmentally relevant concentrations to 2,3,7,8-tetrachlorodibenzo-p-dioxin on survival, growth, reproduction and biochemical responses of female rainbow trout (Oncorhynchus mykiss). - Aquatic Toxicology 59: 35-53.

Gill T.S., Pande J. \& Tewari H. (1990): Sublethal effects of an organophosphorus insecticide on certain metabolite levels in a freshwater fish, Puntius conchonius Hamilton. - Pesticide Biochemistry and Physiology 36: 290-299.

Gonzáles de Canales L.M., Oliva M. \& Garrido C. (2009): Toxicity of lindane ( $\gamma$-hexachlorocyclohexane) in Sparus aurata, Crassostrea angulata and Scrobicularia plana. - Journal of Environmental Science and Health Part B 44: 95-105.

Hooftman R.N. \& de Raat W.K. (1982): Induction of nuclear anomalies (micronuclei) in the peripheral blood erythrocytes of the eastern mudminnow Umbra pygmaea by ethyl methanesulphonate. - Mutation Research 104: 147-152.

Hutz R.J., Carvan M.J. III., B aldridge M.G., Conley I.K. \& King Heiden T. (2006): Environmental toxicants and effects on female reproductive function. - Trends in Reproductive Biology 2: 1-11.

Ivanova N.T. (1983): Atlas kletok krovi ryb (sravnitel'naya morfologiya i klassifikatsiya formennykh elementov krovi ryb). Izdatel'stvo Legkaya i pishchevaya promyshlennost'. Moscow, 184 pp. (in Russian).

Král J. (1988): Examining the efficacy of Menocain (Spofa), 3-aminobenzoic acid sodium hydrogen sulphate ethyl ester, a new anaesthetic for fish. - Biologizace a chemizace živočišné výroby - Veterinaria 24: 101-109. (in Czech with English abstract).

Lake B.G. (1995): Peroxisome proliferation: current mechanisms relating to nongenotoxic carcinogenesis. Toxicology Letters 82/83: 673-681.

Lech J.J. \& Bend J.R. (1980): Relationships between biotransformation and toxicity and fate of xenobiotic chemicals in fish. - Environmental Health Perspectives 34: 115-131.

Lenga R.E (ed.) (1988): Sigma-Aldrich Library of Chemical Safety Data. $2^{\text {nd }}$ ed., Sigma - Aldrich Corp., Milwaukee, WI, USA, 2576 pp.

Lom J. \& Dyková I. (1992). Protozoan Parasites of Fishes. Elsevier, Amsterdam, the Netherlands, 315 pp.

Lopuchovský J. (1986): Interaction of cholecalciferol with polychlorinated biphenyl (Delor 103) in poultry. Biologizace a chemizace živočišné výroby - Veterinaria 22: 433-440. (in Slovak with English abstract).

Lusková V., Svoboda M. \& Kolářová J. (2002): Effect of diazinon on blood plasma biochemistry in carp (Cyprinus carpio L.). - Acta Veterinaria Brno 71: 117-123.

Machala M. (1993): Cytochromes P450. Toxicological significance of level determination. - Veterinarni Medicina 38: 739-750.

Machala M., Nezveda K., Petřívalský P., Jarošová A., Piačka V. \& Svobodová Z. (1997): Monooxygenase activities in carp as biochemical markers of pollution by polycyclic and polyhalogenated aromatic hydrocarbons: choice of substrates and effects of temperature, gender and capture stress. - Aquatic Toxicology 37: 113-123.

Malins D.C., McCain B.B., Brown D.W., Myers M.S., Krahn M.M. \& Chan S. (1987): Toxic chemicals, including aromatic and chlorinated hydrocarbons and their derivatives, and liver lesions in white croaker 
(Genyonemus lineatus) from the vicinity of Los Angeles. - Environmental Science \& Technology 2: 765 770.

Mishra J. \& Srivastava A.K. (1983): Malathion-induced hematological and biochemical changes in the Indian catfish (Heteropneustes fossilis). - Environmental Research 30: 393-398.

Mourad M., Abdallah M. \& Abd-Allah A. (1999): Occurrence of lindane and its effects on some hematological and histological aspects of Tilapia zillii (Gerv.). - Bulletin of the National Institute of Oceanography and Fisheries (Egypt) 25: 237-251.

Myers M.S. \& Rhodes L.D. (1988): Morphologic similarities and parallels in geographic distribution of suspected toxicopathic liver lesions in rock sole (Lepidopsetta bilineata), starry flounder (Platichthys stellatus), Pacific staghorn sculpin (Leptocottus armatus), and Dover sole (Microstomus pacificus), as compared to English sole (Parophrys vetulus), from urban and non-urban embayments in Puget Sound, Washington. - Aquatic Toxicology 11: 410-411.

Myers M.S., Rhodes L.D. \& McCain B.B. (1987): Pathologic anatomy and patterns of occurrence of hepatic neoplasma, putative preneoplastic lesions, and other idiopathic hepatic conditions in English sole (Parophrys vetulus) from Puget Sound, Washington. - Journal of the National Cancer Institute 78: 333-363.

Myers M.S., Landahl J.T., Krahn M.M. \& McCain B.B. (1991): Relationships between hepatic neoplasms and related lesions and exposure to toxic chemicals in marine fish from the U.S. west coast. - Environmental Health Perspectives 90: 7-15.

Myers M.S., Olson O.P., Johnson L.L., Stehr C.S., Homm T. \& Varanasi U. (1992): Hepatic lesions other than neoplasms in subadult flatfish from Puget Sound, Washington: Relationships with indices of contaminant exposure. - Marine Environmental Research 34: 45-51.

Myers M.S., Stehr C.M., Olson O.P., Johnson L.L., McCain B.B., Chan S.L. \& Varanasi U. (1994): Relationships between toxicopathic hepatic lesions and exposure to chemical contaminants in English sole (Pleuronectes vetulus), starry flounder (Platichthys stellatus), and white croaker (Genyonemus lineatus) from selected marine sites on the Pacific Coast, USA. - Environmental Health Perspectives 102: 200-215.

Nandan S.B. \& Nimila P.J. (2012): Lindane toxicity: Histopathological, behavioural and biochemical changes in Etroplus maculatus (Bloch, 1795). - Marine Environmental Research 76: 63-70.

Natarajan G.M. (1989): Changes in the carbohydrate metabolites during acute and chronic exposure of airbreathing fish Channa striatus to oxydemeton methyl (metasystox). - Comparative Physiology and Ecology 14: 181-184.

Nenadic A. \& Springer O. (1991): Histopathological analysis of the effects of lindane on the gills of young rainbow trout (Salmo gairdneri Richardson, 1836). - Veterinarski Archiv 61: 109-116.

Ortiz J.B., Gonzáles de Canales M.L. \& Sarasquete C. (2003): Histopathological changes induced by lindane $(\gamma-\mathrm{HCH})$ in various organs of fishes. - Scientia Marina 67: 53-61.

Petřívalský M., Machala M., Nezveda K., Piačka V., Svobodová Z. \& Drábek P. (1997): Glutathione-dependent detoxifying enzymes in rainbow trout liver: search for specific biochemical markers of chemical stress. - Environmental Toxicology and Chemistry 16: 1417-1421.

Racek J. (ed.) (1999): Clinical Biochemistry. Galén and Karolinum, Praha, 317 pp. (in Czech).

Rhodes J.E., Adams W.J. \& Biddinger R. (1995): Chronic toxicity of 14 phthalate esters to Daphnia magna and rainbow trout (Oncorhynchus mykiss). - Environmental Toxicology and Chemistry 14: 1967-1976.

Roberts R.J. (ed.) (2012): Fish Pathology. Fourth Edition. Wiley-Blackwell, Chichester VIII., 581 pp.

Rehulka J. (2002): Effect of polychlorinated biphenyls Delor 103 on some haematological and biochemical indices of the blood plasma of rainbow trout, Oncorhynchus mykiss (Walbaum). - Diseases of Aquatic Organisms 62: 147-153.

Řehulka J. \& Minařík B. (2008): Total calcium and inorganic phosphate in blood plasma in farmed rainbow trout, Oncorhynchus mykiss. - Aquaculture Research 39: 1161-1168.

- (2012): Cholesterolaemia and triacylglycerolaemia in farmed rainbow trout, Oncorhynchus mykiss. Aquaculture Research 43: 1651-1659.

Řehulka J., Minařík B. \& Řehulková E. (2004): Red blood cell indices of rainbow trout Oncorhynchus mykiss (Walbaum) in aquaculture. - Aquaculture Research 35: 529-546.

Řehulka J., Minařík B., Adamec V. \& Řehulková E. (2005): Investigations of physiological and pathological levels of total plasma protein in rainbow trout, Oncorhynchus mykiss (Walbaum). - Aquaculture Research 36: 22-32.

Sancho E., Ferrando M.D. \& Andreu E. (1997): Sublethal effects of an organophosphate insecticide on the European eel, Anguilla anguilla. - Ecotoxicology and Environmental Safety 36: 57-65.

Singh H.H. \& Srivastava A.K. (1982): Effect of formothion on carbohydrate metabolism in Indian catfish (Heteropneustes fossilis). - Environmental Research 28: 335-339.

Smith L.S. (1991): Generalized stress response. In: Smith L.S. (ed.). Introduction to fish physiology. Argent Laboratories Press, p. 282-287. 
Soengas J.L., Strong E.F., Aldegunde M. \& Andres M.D. (1997): Effects of an acute exposure to lindane (gamma-hexachlorocyclohexane) on brain and liver carbohydrate metabolism of rainbow trout. Ecotoxicology and Environmental Safety 38: 99-107.

Srivastava A.K. (1981): Effects of acute exposure of methyl parathion on carbohydrate metabolism of Indian catfish (Heteropneustes fossilis). - Acta Pharmacologica et Toxicologica 48: 26-34.

Svobodová Z. (1971): Some haematological and metabolic changes occurring in fish after pesticide intoxication. - Bulletin VÚR Vodňany 7: 29-36. (in Czech with English abstract).

Svobodová Z. \& Pečená M. (1988): Changes in the red and white blood picture of carp after acute exposure to toxic substances. - Papers of R.I.F.H. Vodňany 17: 116-128.

Tierney K.B., Farell P. \& Brauner C.J. (eds) (2014): Organic Chemical Toxicology of Fishes. Fish Physiology Volume 33. Academic Press, 545 pp.

Tripathi M., Mishra R.P. \& Girdoniya V. (2012): Histopathological changes in gallbladder of a teleost fish Catla catla treated with $1.2 \%$ lindane. - Journal of Fisheries and Aquaculture 3: 44-46.

Unistat 6.0 (2011): Statistical Package for Windows. User's Guide, Version 6.0. Unistat House, Shirland Mews, 4, London W9 3DY, England, 930 pp.

Walter G.L., Jones P.D. \& Giesy J.P. (2000): Pathologic alterations in adult rainbow trout, Oncorhynchus mykiss, exposed to dietary 2,3,7,8-tetrachlorodibenzo-p-dioxin. - Aquatic Toxicology 50: 287-299.

van Wezel A.P., van Vlaardingen P., Posthumus R., Crommentuijn G.H. \& Sijm D.T.H.M. (2000): Environmental risk limits for two phthalates, with special emphasis on endocrine disruptive properties. Ecotoxicology and Environmental Safety 46: 305-321.

Verma S.R., Gupta S.P. \& Tyagi M.P. (1975): Studies on the toxicity of lindane on Colisa fasciatus (part I.: TLm measurements and histopathological changes in certain tissues). - Gegenbaurs Morphologisches Jahrbuch 121: 38-54.

Własow T. (1985): The leucocyte system in rainbow trout, Salmo gairdneri Rich. affected by prolonged subacute phenol intoxication. - Acta Ichthyologica et Piscatoria 15: 83.

Authors' addresses: Jiří Ř $\quad$ Nahulka, Department of Zoology, Silesian Museum, CZ-746 01 Opava, Nádražní okruh 33, Czech Republic, e-mail address: rehulka@szm.cz

Bohumil Minařík, Department of Mathematics, College of Polytechnics, Jihlava, Czech Republic

Miroslav Machala, Veterinary Research Institute, Brno, Czech Republic 